\title{
Is Guillain-Barrè syndrome triggered by SARS-CoV-2? Case report and literature review
}

\author{
Edoardo Agosti ${ }^{1}$ (D) Andrea Giorgianni ${ }^{2} \cdot$ Francesco D'Amore $^{2} \cdot$ Gabriele Vinacci $^{3} \cdot$ Sergio Balbi $^{1} \cdot$ Davide Locatelli $^{1}$
}

Received: 30 May 2020 / Accepted: 2 July 2020 / Published online: 9 July 2020

(C) The Author(s) 2020

\begin{abstract}
Background Severe acute respiratory syndrome coronavirus 2 (SARS-CoV-2) is the infectious agent responsible for coronavirus disease 2019 (COVID-19). Respiratory and gastrointestinal manifestations of SARS-CoV-2 are well described, less defined is the clinical neurological spectrum of COVID-19. We reported a case of COVID-19 patient with acute monophasic Guillain-Barré syndrome (GBS), and a literature review on the SARS-CoV-2 and GBS etiological correlation.

Case Description A 68 years-old man presented to the emergency department with symptoms of acute progressive symmetric ascending flaccid tetraparesis. Oropharyngeal swab for SARS-CoV-2 tested positive. Neurological examination showed bifacial nerve palsy and distal muscular weakness of lower limbs. The cerebrospinal fluid assessment showed an albuminocytologic dissociation. Electrophysiological studies showed delayed distal latencies and absent $\mathrm{F}$ waves in early course. A diagnosis of Acute Inflammatory Demyelinating Polyradiculoneuropathy (AIDP) subtype of GBS was then made.

Conclusions Neurological manifestations of COVID-19 are still under study. The case we described of GBS in COVID-19 patient adds to those already reported in the literature, in support of SARS-CoV-2 triggers GBS. COVID-19 associated neurological clinic should probably be seen not as a corollary of classic respiratory and gastrointestinal symptoms, but as SARS-CoV2-related standalone clinical entities. To date, it is essential for all Specialists, clinicians and surgeons, to direct attention towards the study of this virus, to better clarify the spectrum of its neurological manifestations.
\end{abstract}

Keywords SARS-CoV-2 $\cdot$ COVID-19 $\cdot$ Guillain-Barrè · AIDP $\cdot$ Neuropathy $\cdot$ Para-infectious

\section{Background}

Severe acute respiratory syndrome coronavirus 2 (SARSCoV-2) is the infectious agent of coronavirus disease 2019 (COVID-19). Starting from the first case recorded in Wuhan (China) in December 2019, SARS-CoV-2 quickly spread around the world, leading the World Health Organization to declare pandemic [1]. To date, June 6th, 2020, the confirmed

Edoardo Agosti

edoardo_agosti@libero.it

1 Division of Neurosurgery, Department of Biotechnology and Life Sciences, University of Insubria, Via Guicciardini, 9, 21100 Varese, Italy

2 Department of Neuroradiology, ASST Sette Laghi, University of Insubria, Varese, Italy

3 Department of Radiology, University of Insubria, Varese, Italy cases in the world are around 6.6 million and more than 390,000 deaths [2].

COVID-19 is a systemic infection that usually presents with fatigue and fever. The most frequent symptoms described are respiratory and gastrointestinal [3]. However, neurological complications have recently been reported, including dizziness, headache, febrile seizures, myalgia, encephalopathy, encephalitis, stroke, and acute peripheral nerve diseases $[4,5]$.

Some cases of Acute Motor and Sensory Axonal Neuropathy (AMSAN) and acute inflammatory demyelinating polyradiculoneuropathy (AIDP) subtypes of GuillainBarré syndrome (GBS) have recently been described. GBS is an acute immune-mediated polyradiculoneuropathy often related to previous infectious exposure [6-8]. Clinically, GBS is characterized by limbs or cranial-nerve weakness, loss of deep tendon reflexes, sensory, and dysautonomic symptoms due to peripheral nerves and root demyelination and/or axonal damage [9]. About $60 \%$ of all GBS are preceded by respiratory or a gastrointestinal [10]. 
We reported a case of COVID-19 patient with AIDP subtype of GBS, associating a literature review on the SARSCoV-2 and GBS etiological correlation.

\section{Case description}

On April 26th, 2020, a 68-year-old man presented to the emergency department with symptoms of acute progressive symmetric ascending flaccid tetraparesis. Patient medical history included dyslipidemia, benign prostatic hypertrophy, hypertension, and abdominal aortic aneurysm in follow-up. Ten days before admission, dry cough associated with fever, dysgeusia, and hyposmia appeared. Neurological manifestations started 5 days later with progressive acute weakness of distal lower extremities.

On admission, oxygen saturation was $96 \%$ on room air, with a respiratory rate of 17 breaths/min, and the body temperature was $37.2^{\circ} \mathrm{C}$. Chest computed tomography highlighted a bilateral basilar ground glass opacity, with oropharyngeal swab positive for SARS-CoV-2 on reverse transcriptasepolymerase chain reaction (RT-PCR) assay. No pathological findings were auscultated on pulmonary objective examination.

The patient was then isolated and antiviral drugs have been started. Neurological examination showed bifacial nerve palsy (House-Brackmann grade 3) and muscular weakness, with a Medical Research Council scale of $1 / 5$ in proximal and 2/5 in distal of the lower limbs. The osteo-tendon reflexes were hypoactive with bilateral areflexia to the Achilles tendons. No sensory deficit was recorded. Upper motor neuron disorder or meningeal irritation signs have not been found.

Baseline laboratoristic analysis showed thrombocytopenia $\left(101 \times 10^{9} / \mathrm{L}\right.$, reference value: $\left.125-300 \times 10^{9} / \mathrm{L}\right)$ and lymphocytopenia $\left(0.48 \times 10^{9} / \mathrm{L}\right.$, reference value: $1.1-3.2 \times$ $\left.10^{9} / \mathrm{L}\right)$. Cerebrospinal fluid assessment showed an albuminocytologic dissociation with increased protein level (98 $\mathrm{mg} / \mathrm{dL}$, reference value: $8-43 \mathrm{mg} / \mathrm{dL}$ ) and normal cell count $\left(2 \times 10^{6} / \mathrm{L}\right.$, reference value: $\left.0-8 \times 10^{6} / \mathrm{L}\right)$. Additional serological tests (i.e., ANA, anti-DNA, c-ANCA, p-ANCA, Campylobacter jejuni, Mycoplasma pneumoniae, Salmonella enterica, Cytomegalovirus, Epstein-Barr virus, herpes simplex virus 1 and 2, Varicella-Zoster virus, influenza virus A and $\mathrm{B}$, human immunodeficiency virus) were negative. Normal serum vitamin B12 level and serum protein electrophoresis were found.

Four days after neurological symptoms and signs onset, motor nerve conduction studies showed delayed distal latencies and absent $F$ waves in early course, supporting demyelinating pattern in accordance with GBS diagnostic criteria (Table 1). Sensory nerve conduction showed nerve action potentials; the recorded values were all in range, in line with the patient clinic.
A diagnosis of Guillain-Barré syndrome was then made. Intravenous immunoglobulin was administered at a dose of $0.4 \mathrm{~g} / \mathrm{kg}$ for 5 days. Thrombocytopenia and lymphocytopenia progressively returned in the following days, with complete resolution of the admission radiological pulmonary findings. The improvement of the respiratory and laboratory clinic was followed by a progressive recovery of limb strength and a return to osteo-tendon normoreflexia. Thirty days after hospitalization, following the negative result of the oropharyngeal swab for SARS-CoV-2, the patient was discharged to continue the rehabilitation program at home.

\section{Discussion}

We described a case of acute progressive symmetric ascending flaccid tetraparesis in a COVID-19 patient with diagnosis of AIDP subtype of GBS. The anamnestic, clinical, electrophysiological, and laboratory evidence leads to a likely causal association with SARS-CoV-2.

Starting from the first case of GBS SARS-CoV-2 infectionrelated described by Zhao $\mathrm{H}$. et al. [11], a series of cases have been reported in the literature, supporting the post-infectious and para-infectious etiopathological correlation between SARS-CoV-2 and this acute polyradiculoneuropathy (Table 2). A systematic review of the literature on GBS and its correlation with SARS-CoV-2 infection was performed. Multiple searches were made on PubMed and Scopus by cross-referencing the following keywords: "Guillan-Barrè", "Guillan-Barrè syndrome", "COVID-19", "SARS-CoV-2", "para-infectious", "post-infectious", "molecular mimicry", "neuropathy", "flaccid", "polyradiculoneuropathy", "ACE2", "pathogenesis". Other pertinent articles were retrieved through reference analysis. Inclusion criteria were the report of GBS clinical manifestation in COVID-19 patients. To date, June 6th, 2020, 16 papers have been published regarding the GBS-SARS-CoV-2 correlation. Adding up all the cases reported in the literature, 23 COVID-19 patients with GBS have been described, including our case report. There was no gender prevalence, and the average age of the patients was 61 years. A slight prevalence of AIDP over AMSAN subtype was observed. Post-infectious cases were predominant over para-infectious cases.

GBS is an acute flaccid paralytic disease that most commonly presents with progressive symmetric weakness and areflexia. GBS usually occurs following a respiratory or gastrointestinal infection, with a presentation latency varying between 3 days and 6 weeks [9]. The supposed pathophysiological mechanism is the "molecular mimicry", an aberrant autoimmune response to a preceding infection which evokes a cross-reaction against the peripheral nerve antigens (e.g. production of anti-ganglioside antibodies in AMSAN GBS subtype preceded by Campylobacter jejuni infection) [9]. For this 


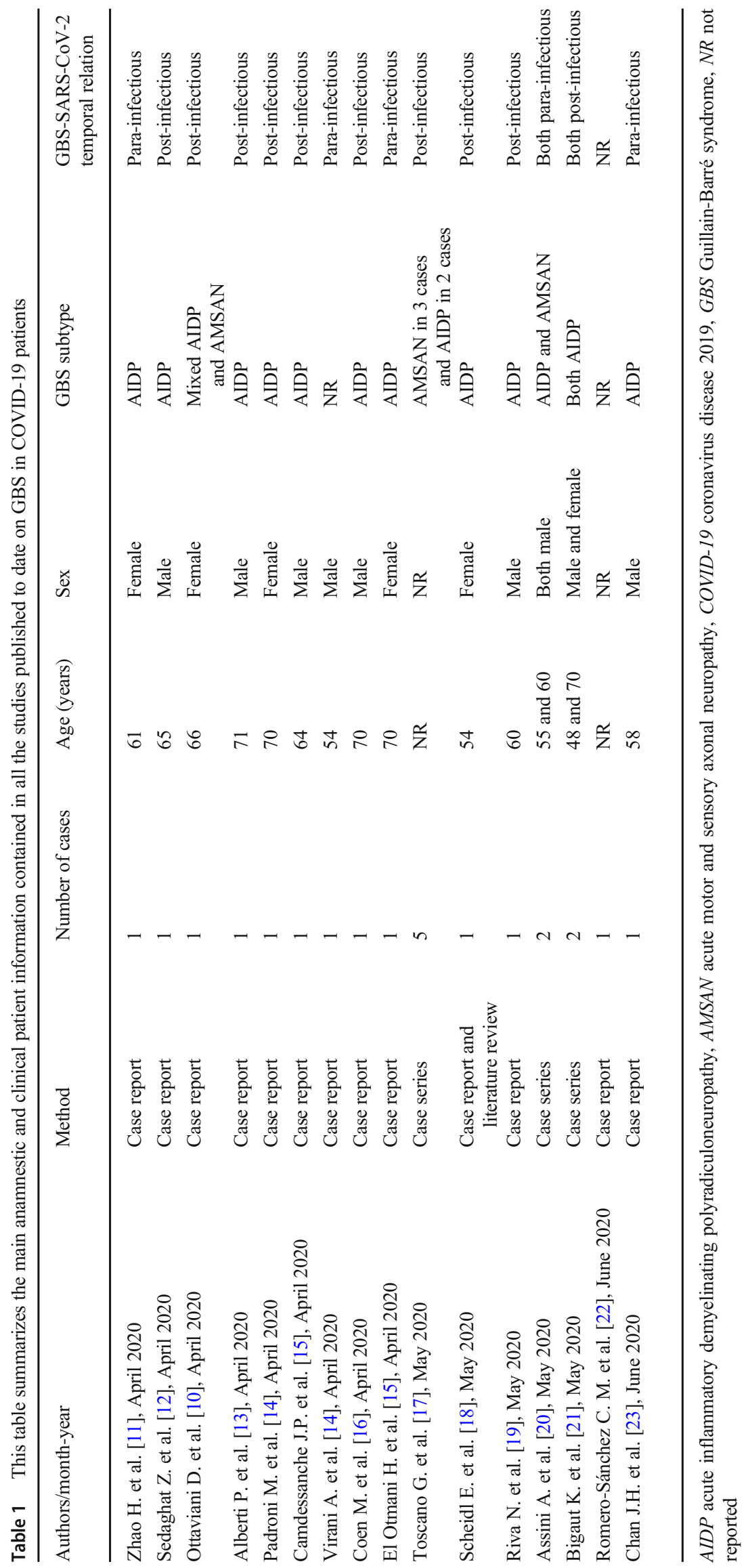


reason, GBS can be defined as para-infectious neurological disease [4]. SARS-CoV-2 nervous tissue damage can be both related to the direct neuroinvasive action (through direct binding with ACE-2 receptors) [24] and to an indirect injury of the immune system. In the latter case, the mechanism of immunemediated damage can be due both to an overactivation of the immune system with hyperproduction of interleukin-6, and to the generation of an autoimmune reaction [18].

The infectious bacterial agents classically associated with GBS are Campylobacter jejuni, which is the most frequent, Mycoplasma pneumoniae, and Haemophilus influenzae; Cytomegalovirus, Epstein-Barr virus, and Influenza-A virus are the most involved viral pathogens [9]. Cases associated with hepatitis $E$ virus infection and measle infection have also rarely been found [25, 26]. In 2015 and 2016, cases of GBS related to the Zika virus were also reported [10, 27]. In addition, recent evidence reported some cases of GBS in COVID19 patients, to the point of speculating a possible association between the acute polyradiculopathy and SARS-CoV-2 infection $[10-23,28,29]$.

Post-infectious refers to patients with GBS arisen once the SARS-CoV-2 infection has resolved, while para-infectious if GBS occurred during COVID-19 [14]. In our case, the respiratory clinic slightly preceded the appearance of neurological symptoms, while the pulmonary, laboratory and radiological positivity to SARS-CoV-2 accompanied the whole clinical course of GBS, to have an almost parallel resolution. These data are suggestive for a para-infectious mechanism.

As well described in the literature, GBS is an immunemediated disorder due to a molecular mimicry mechanism [9]. However, a real verification of the production of specific antibodies against gangliosides present on the surface of the nerve myelin sheaths is still lacking [12]. For this reason, further studies are needed to better clarify the pathophysiological mechanism of GBS in patients with COVID-19.

The diagnosis of SARS-CoV-2-related GBS in our patient was supported by a series of laboratory findings associated with the incipient clinic and electrophysiological data. In particular, the serologies of the most common pathogens associated with GBS, such as Campylobacter jejuni, Mycoplasma pneumoniae, Salmonella enterica, Cytomegalovirus, EpsteinBarr virus, herpes simplex virus 1 and 2, Varicella-Zoster virus, influenza virus $\mathrm{A}$ and $\mathrm{B}$, and human immunodeficiency virus, were negative. Antibody tests for GBS-associated autoimmune diseases (e.g., ANA, anti-DNA, c-ANCA, p-ANCA) were also negative. Furthermore, in support of GBS diagnosis, we observed a marked albuminocytologic dissociation. However, we cannot prove with certainty that a COVID-19 para-infectious AIDP subtype of GBS has occurred, as the sensitivity RT-PCR test of the oropharyngeal swab is suboptimal [14]. Furthermore, some rarer but endemic Northern Italy infectious agents that can be related to para-infectious GBS, such as West Nile virus and Toscana Virus, have not 
been tested [14]. Besides, adequate paraneoplastic screening was not performed, and antiganglioside antibodies were not studied. Despite this, based on the anamnestic, laboratory, neurophysiological, and clinical data collected, we can support the correlation between the onset of GBS and COVID-19, in line with emerged data of the literature review.

\section{Conclusion}

While it is well known that SARS-CoV-2 correlates with respiratory and gastrointestinal manifestations, systemic and neurological involvement is still being studied. The case we described of GBS in a COVID-19 patient adds to those already reported in the literature, in support of SARS-CoV-2 triggering of GBS.

The aim of this work is to shed more light on the neurological manifestations of COVID-19, not as a corollary of classic respiratory and gastrointestinal symptoms, but as SARS-CoV2-related standalone clinical entities. To date, it is essential for all specialists, clinicians, and surgeons, to direct attention towards the study of this virus, in order to clarify the spectrum of its neurological manifestations.

Acknowledgements Open access funding provided by Università degli Studi dell'Insubria within the CRUI-CARE Agreement.

\section{Compliance with ethical standards}

Conflict of Interest The authors declare that they have no conflict of interest.

Ethical approval All procedures performed in studies involving human participants were in accordance with the ethical standards of the institutional and/or national research committee and with the 1964 Helsinki declaration and its later amendments or comparable ethical standards.

Institutional review board approval Informed consent was obtained from all individual participants included in the study.

Consent for publication Consent for publication was obtained for every individual person's data included in the study.

Open Access This article is licensed under a Creative Commons Attribution 4.0 International License, which permits use, sharing, adaptation, distribution and reproduction in any medium or format, as long as you give appropriate credit to the original author(s) and the source, provide a link to the Creative Commons licence, and indicate if changes were made. The images or other third party material in this article are included in the article's Creative Commons licence, unless indicated otherwise in a credit line to the material. If material is not included in the article's Creative Commons licence and your intended use is not permitted by statutory regulation or exceeds the permitted use, you will need to obtain permission directly from the copyright holder. To view a copy of this licence, visit http://creativecommons.org/licenses/by/4.0/.

\section{References}

1. WHO Director-General's opening remarks at the media briefing on COVID-19 - 11 March 2020. https:/www.who.int/dg/speeches/ detail/who-director-general-s-opening-remarks-at-the-mediabriefing-on-covid-19-11-march-2020

2. Track reported cases of COVID-19

3. Vetter P, Lan Vu D, L'Huillier AG, Schibler M, Kaiser L, Jacquerioz F (2020) Clinical features of covid-19. BMJ. 369: m1470. https://doi.org/10.1136/bmj.m1470

4. Needham EJ, Chou SH-Y, Coles AJ, Menon DK (2020) Neurological implications of COVID-19 infections. Neurocrit Care 32:667-671. https://doi.org/10.1007/s12028-020-00978-4

5. Ahmad I, Rathore FA (2020) Neurological manifestations and complications of COVID-19: a literature review. J Clin Neurosci 77:812. https://doi.org/10.1016/j.jocn.2020.05.017

6. Cosi V, Versino M (2006) Guillain-Barré syndrome. Neurol Sci 27: S47-S51. https://doi.org/10.1007/s10072-006-0548-4

7. De Andrade da Silva R, Carvalho Cremaschi R, Rebello Pinho JR, Bosco de Oliveira J, Morgadinho Coelho F (2019) Guillain-Barré syndrome - the challenge of unrecognized triggers. Neurol Sci 40(11):2403-2404. https://doi.org/10.1007/s10072-019-03926-z

8. Guillain-Barré Syndrome Study Group (2000) Guillain-Barré syndrome: an Italian multicentre case-control study. Neurol Sci 21(4): 229-234. https://doi.org/10.1007/s100720070081

9. Van Doorn PA, Ruts L, Jacobs BC (2008) Clinical features, pathogenesis, and treatment of Guillain-Barrè syndrome. Lancet Neurol 7:939-950. https://doi.org/10.1016/S1474-4422(08)70215-1

10. Ottaviani D, Boso F, Tranquillini E, Gapeni I, Pedrotti G, Cozzio S, Guarrera GM, Giometto B (2020) Early Guillain-Barré syndrome in coronavirus disease 2019 (COVID-19): a case report from an Italian COVID-hospital. Neurol Sci. https://doi.org/10.1007/ s10072-020-04449-8

11. Zhao H, Shen D, Zhou H, Liu J, Chen S (2020) Guillain-Barré syndrome associated with SARS-CoV-2 infection: causality or coincidence? Lancet Neurol 19:383-384. https://doi.org/10.1016/ S1474-4422(20)30109-5

12. Sedaghata Z, Karimib N (2020) Guillain Barre syndrome associated with COVID-19 infection: a case report. J Clin Neurosci 76:233235. https://doi.org/10.1016/j.jocn.2020.04.062

13. Alberti P, Beretta S, Piatti M, Karantzoulis A, Piatti ML, Santoro P, Viganò M, Giovannelli G, Pirro F, Montisano DA, Appollonio I, Ferrarese C (2020) Guillain-Barré syndrome related to COVID-19 infection. Neurol Neuroimmunol Neuroinflamm 29:7. https://doi. org/10.1212/NXI.0000000000000741

14. Padroni M, Mastrangelo V, Asioli GM, Pavolucci L, AbuRumeileh S, Piscaglia MG, Querzani P, Callegarini C, Foschi M (2020) Guillain-Barrè syndrome following COVID-19: new infection, old complication? J Neurol 267:1877-1879. https://oi.org/ 10.1007/s00415-020-09849-6

15. El Otmani H, El Moutawakil B, Rafai M-A, El Benna N, El Kettani C, Soussi M, El Mdaghri N, Barrou H, Afif H (2020) Covid-19 and Guillain-Barré syndrome: more than a coincidence! Rev Neurol (Paris) 176:518-519. https://doi.org/10.1016/j.neurol.2020.04.007

16. Coen M, Jeanson G, Culebras Almeida LA, Hübers A, Stierlin F, Najjar I, Ongaro M, Moulin K, Makrygianni M, Leemann B, Kronig I, Bertrand J, Reny JL, Schibler M, Serratrice J (2020) Guillain-Barré syndrome as a complication of SARS-CoV-2 infection. Brain Behav Immun S0889-1591:30698-3069X. https://doi. org/10.1016/j.bbi.2020.04.074

17. Toscano G, Palmerini F, Ravaglia S, Ruiz L, Invernizzi P, Cuzzoni MG, Franciotta D, Baldanti F, Daturi R, Postorino P, Cavallini A, Micieli G (2020) Guillain-Barré syndrome associated with SARSCoV-2. N Engl J Med 382:2574-2576. https://doi.org/10.1056/ NEJMc2009191 
18. Scheidl E, Diez Canseco D, Hadji-Naumov A, Bereznai (2020) Guillain-Barre syndrome during SARS-CoV-2 pandemic: a case report and review of recent literature. JPNS. 25:204-207. https:// doi.org/10.1111/jns.12382

19. Riva N, Russo T, Falzone YM, Strollo M, Amadio S, Del Carro U, Locatelli M, Filippi M, Fazio R (2020) Post-infectious GuillainBarré syndrome related to SARS-CoV-2 infection: a case report. J Neurol 26:1-3. https://doi.org/10.1007/s00415-020-09907-z

20. Assini A, Benedetti L, Di Maio S, Schirinzi E, Del Sette M (2020) New clinical manifestation of COVID-19 related Guillain-Barrè syndrome highly responsive to intravenous immunoglobulins: two Italian cases. Neurol Sci. https://doi.org/10.1007/s10072-02004484-5

21. Bigaut K, Mallaret M, Baloglu S, Nemoz B, Morand P, Baicry F, Godon A, Voulleminot P, Kremer L, Chanson J-B, De Seze J (2020) Guillain-Barrè syndrome related to SARS-CoV-2 infection. https://doi.org/10.1212/NXI.0000000000000785

22. Romero-Sánchez CM, Díaz-Maroto I, Fernández-Díaz E, SánchezLarsen A, Layos-Romero A, García-García J, González E, Redondo-Peñas I, Perona-Moratalla AB, Del Valle-Pérez JA, Gracia-Gil J, Rojas-Bartolomé L, Feria-Vilar I, Monteagudo M, Palao M, Palazón-García E, Alcahut-Rodríguez C, SopelanaGaray D, Moreno Y, Ahmad J, Segura T (2020) Neurologic manifestations in hospitalized patients with COVID-19: the ALBACOVID registry. Neurology:10.1212/ WNL.0000000000009937. https://doi.org/10.1212/WNL. 0000000000009937

23. Chan JC, Ebadi H, Sarna JR (2020) Guillain-Barré syndrome with facial diplegia related to SARS-CoV-2 infection. Can J Neurol Sci: 1-3. https://doi.org/10.1017/cjn.2020.106
24. Baig AM, Khaleeq A, Ali U, Syeda H (2020) Evidence of the COVID-19 virus targeting the CNS: tissue distribution, host-virus interaction, and proposed neurotropic mechanisms. ACS Chem Neurosci:995-998. https://doi.org/10.1021/acschemneuro.0c00122

25. Fukae J, Tsugawa J, Ouma S, Umezu T, Kusunoki S, Tsuboi Y (2016) Guillain-Barrè and Miller Fisher syndromes in patients with anti-hepatitis E virus antibody: a hospital-based survey in Japan. Neurol Sci 37(11):1849-1851. https://doi.org/10.1007/s10072016-2644-4

26. Filia A, Lauria G (2014) Guillain-Barrè syndrome following measles infection: case report and review of the literature. Neurol Sci 35(12):2017-2018. https://doi.org/10.1007/s10072-014-1841-2

27. Cao-Lormeau VM, Blake A, Mons S, Lastère S, Roche C, Vanhomwegen J, Ghawché F (2016) Guillain-Barré syndrome outbreak associated with Zika virus infection in French Polynesia: a case-control study. Lancet. 387:1531-1539. https://doi.org/10. 1016/S0140-6736(16)00562-6

28. Virani A, Rabold E, Hanson T, Haag A, Elrufay R, Cheema T, Balaan M, Bhanotc N (2020) Guillain-Barré syndrome associated with SARS-CoV-2 infection. IDCases. 20:e00771. https://doi.org/ 10.1016/j.idcr.2020.e00771

29. Camdessanche JP, Morel J, Pozzetto B, Paul S, Tholance Y, Botelho-Nevers E (2020) COVID-19 may induce Guillain-Barré syndrome. Rev Neurol (Paris) S0035-3787:30522-30521. https:// doi.org/10.1016/j.neurol.2020.04.003

Publisher's note Springer Nature remains neutral with regard to jurisdictional claims in published maps and institutional affiliations. 